\title{
The Short Play and Postmodernist Stage Directing: A Virtual EXPERIMENT With Pirandello's CECÈ
}

\section{STEFANO BOSELLI}

\begin{abstract}
Summary: The one-act play Cecè (1913) by Luigi Pirandello belongs to the playwright's early production and has been rightly praised for its perfect comic mechanism. Yet, it has heretofore attracted little attention in the academic world. Despite containing one of the first instances of the author's approach to the instability of self, one of the reasons why its depth appears limited, resides in its brevity when compared to Pirandello's major works. However, its very economy may allow a director to be experimental and offer multiple versions and perspectives to the audience in a single evening, showcasing a variety of critical theories.
\end{abstract}

If a stage director intrigued by critical theory decided to adopt a postmodernist approach, he or she would find little practical advice in publication. In her recent The Theater of Transformation: Postmodernism in American Drama, Kerstin Schmidt observes that "drama and theater play ancillary roles at best in many of the classic commentaries on postmodernism."1 In truth, a few studies such as Mark Fortier's Theory/Theatre or Peter Buse's Drama + Theory established lines of communication between the theatre and a spectrum of critical positions. However, the notion of postmodernism alone is a terminological and conceptual minefield even for specialists. ${ }^{2}$ As for the practical side, making complex ideas visible on the stage may feel like an unnecessary addition to the already daunting semiotic density of a play in performance. All in all, the divide between theorists and theatre practitioners continues to exist.

1 Schmidt, The Theater of Transformation, 9.

2 Volumes have been written in an attempt to define this protean, even "exasperating term" and its derivatives (Bertens, The Idea of the Postmodern, 3), depending on historical period, theoretical and artistic field, or personal preference. For the purposes of this article, I use the term "postmodernist" - rather than "postmodern" to refer to "a structure of feeling, an episteme, rather than a chronologically defined moment" (Auslander, "Postmodernism and Performance," 98). At the same time, to simplify things considerably, "postmodernist" functions here as near synonym of "deconstructionist," since I refer mainly to thinkers operating between the 1970s and 80s when deconstruction became postmodernism's "operative theoretical strategy" (Silverman, "Jacques Derrida," 110). 
Along the lines of Roland Barthes's seminal essays "The Death of the Author" and "From Work to Text," a postmodernist director could begin from a more flexible relationship with the dramatist and the playtext, whose combined authority has long remained a staple of Western theatre. By emphasizing the freedom for interpreters, this attitude contributed to what has been termed "director's theatre." Still, in many ways, the director remains the last bulwark of logocentrism on the stage. ${ }^{3}$ If the essence of postmodernism, in the words of François Lyotard, is an "incredulity toward metanarratives," 4 how can directors escape the temptation to believe in the ultimate metanarrative of their own singular viewpoint?

As a way for the director to fruitfully connect postmodernist theory with practice, this article suggests a strategy based on the little acknowledged potential of the short play in combination with the richness of repetition. 5

On the whole, thanks to its brevity, the short play calls for the presence of more than one work during the same event, thereby allowing a stronger degree of intertextual interaction. A full-length play tends to occupy the entire time of the performance and may sound like the only voice allowed to speak. By contrast, the short play is genetically predisposed to multiplicity and encourages contextual dialogue between authors, playtexts, and interpreters. ${ }^{6}$ Provided that the plays were written by different dramatists, this heightened intertextuality may help de-emphasize the Author and the Work in favor of the Text. But enhancing intertextuality alone does not automatically touch the director's role.

One way to tackle the deconstruction of the director's omnipotent

3 Even after several origins of the Western Logos have been declared dead (God by Nietzsche, the Author by Barthes, and the Character by Fuchs), production practices have remained substantially unchanged. "In traditional theatre" says Rabkin, "the director perceives his integrative role as subordinate to the dramatic text; in experimental theatre, the playwright's authority is often preempted, ignored, or overthrown. But apart from a few collectivist challenges, the director's central authority in creating the performance text is accepted" ("The Play of Misreading," 55).

4 Lyotard, The Postmodern Condition, xxiv.

5 Eco contrasted modernist with postmodernist aesthetics by comparing the value attributed to repetition: the modernists relegate it to crafts and industry, since they appreciate innovation and novelty at all costs; conversely, postmodernists treasure repetition because it allows "organized differentiations, polycentrism, regulated irregularity" ("Innovation and Repetition," 30). In Difference and Repetition, Deleuze illuminated the concept of repetition not as the occurrence of the same, a Platonic copy, but as continued experimentation and creative discovery.

6 Boselli, "The Intertextual Short Play," 48-51. 
vision is to repeat the same play more than once in sequence, in different interpretations each time, in a decentered series always open to additional insights. 7 Hence, the postmodernist/self-deconstructive director needs to collaborate with other directors on the same project, or, at least, listen to a plurality of contrasting voices within. Thus, the first step is to find a suitable short play that is as open as possible to interpretation, a text whose Model Reader is free to choose numerous, even contradictory viewpoints, a "writerly text" in Barthesian terms, that allows a more active collaboration of the interpreter as producer of meaning. ${ }^{8}$ Among Pirandello's oneact plays, the frequently neglected Cecè shines as a very promising ground for playful experimentation.

\section{Pirandello’s Cecè: A Writerly Play}

CECÈ. If I think about it, I'll go crazy! Now tell me, isn't it hell to realize that you live chopped up into a hundred thousand pieces for a hundred thousand other people??

Pirandello wrote Cecè in July 1913 in an early phase of his career: it was his first play not derived from an existing narrative idea. ${ }^{10}$ Instead of handing the script directly to actor Achille Vitti or impresario Lucio d'Ambra, both involved in the production of his latest three one-acts, this time he sent the

7 In fact, each of these interpretations can only be provisional, a misreading, a supplement to the others. Derrida distinguishes interpretations that seek to discover the point of origin and ultimate truth from interpretations that adopt a playful disposition (Writing and Difference, 292). The play of signs might continue indefinitely, constantly contradicting the idea of a fixed center and postponing closure.

${ }^{8}$ Eco sees a text as "a device conceived in order to produce its Model Reader. [...] this reader is not the one who makes the 'only right' conjecture. A text can foresee a Model Reader entitled to try infinite conjectures" (The Limits of Interpretation, 58-59). Barthes distinguishes between "readerly" and "writerly" texts. While the former assume a predetermined interpretation, the latter "make the reader no longer a consumer, but a producer of the text" $(S / Z, 4)$.

${ }^{9}$ Murray, Chee-Chee, 144.

10 Luti defined it "an absolute hapax among the whole of [Pirandello's] one-acts" ("Struttura degli atti unici di Pirandello," 150); d'Amico noted that "among the regular vegetation of short stories which, during that period, was getting thicker at the rhythm of one each month, this one-act play seems to have sprouted by chance, on an untrodden path, from a seed brought by the wind" (Notizia, 105). If not otherwise indicated, all translations are my own. 
play for publication to the review Lettura, since the printed version guaranteed bigger and more immediate profits. The editor, Renato Simoni, promised to publish it in October. ${ }^{11}$ Cecès theatrical premiere took place more than two years later at the Orfeo Theatre in Rome, an example of those "minimal theatres" dedicated to the staging of shorter plays in competition with cinema. ${ }^{12}$ When the playwright undertook the overall revision of his dramatic works in 1925 for the Bemporad edition, the script of Cecè remained substantially unchanged, despite rehearsals, performances, and the direct professional experience Pirandello had accrued in the meantime. This rare stability of the Pirandellian script may be interpreted as authorial indifference, ${ }^{13}$ but it is also an indication of the excellence of its perfect mechanism.

The script can be segmented in three parts in relation to the presence, each time, of two of the three characters, never all together on the stage:

1. Cecè - Squatriglia. While Cecè is in the bathroom of his hotel room for his morning grooming, commendator Squatriglia stops by to thank him in person for a favor he recently received. Squatriglia has a grotesque appearance: he lost an eye in an accident and had the wound sealed with a skin graft. Cecè cannot remember exactly what he did for him, since he initially mistakes him for his brother. Nevertheless, he soon decides to make the most of Squatriglia's gratitude and asks him to play a part. When Nada, Cecè's current lover, arrives, the commendatore's task will be to retrieve the three IOUs Cecè gave her as he tried to gain her sympathy and win a bet with his friends.

2. Squatriglia - Nada. Squatriglia is a terrible actor, but, when Nada arrives, he gradually finds inspiration. Following his benefactor's suggestion, he begins lamenting an alleged bankruptcy of Cecè's family, which would render the IOUs worthless. Eventually, he obtains the desired restitution; yet, in exchange, he needs to hand her roughly a fourth of the sum in cash, which she claims will serve to pay a bill with the milliner. Exhausted by the performance, Squatriglia leaves, while Nada grows increasingly furious because of the information Cecè seems to have withheld.

3. Nada - Cecè. Cecè finally enters, pretends to ignore Squatriglia’s visit completely, and then simulates the fear that the man might be a usurer ready to blackmail him. Taking advantage of the woman's compassion, he convinces her both to yield Squatriglia's money and to offer sexual favors in exchange

11 d'Amico, Notizia, 105.

12 The first had been Nino Martoglio's Teatro Minimo in Rome during the season of 1910-11. The premiere of Cecè took place on 14 December 1915 with four repeats the following evenings.

13 Luti views it as "an immediately abandoned path" ("Struttura degli atti unici di Pirandello," 150). 
for the remainder of the sum. On their first kisses, obviously leading to much more risqué action, the curtain descends quickly.

Despite a few productions in its history, Cecè enjoyed very little critical fortune on either page or stage. ${ }^{14}$ When the play is considered at all, its main qualities are identified in its originality and lightness. Giorgio Pullini emphasizes its freedom from naturalistic molds based on traditional formulas of morality, which allows the play to move freely in response to the pleasure of a grotesque imagination. ${ }^{15}$ For Nino Borsellino, the absence of a narrative precedent seems to more readily anticipate the requests of theatre troupes. ${ }^{16}$ Yet, someone questions the play's originality in theatrical terms speaking of "a failed assay [. . . an experimental attempt at a farcical structure in conformity with the tried mechanisms of the contemporary comic repertory." 17 Often, this "little wordly game" 18 has been "dismissed as a lightweight pochade, in which one finds, somewhat inappropriately, a rather serious monologue expressing Pirandello's ideas on the nature of human identity." 19

Undoubtedly, Cecè may seem a trifle: the analysis remains on the surface and lacks the alluring shadows and internal ruminations that confer depth to the major works of the dramatist's maturity. Furthermore, critical references to a licentious raisonneur in the style of Boccaccio ${ }^{20}$ or to the tradition of the hoax genre in which intelligence prevails ${ }^{21}$ characterize this play as simply modern and lucidly Cartesian, whereas its detractors prefer

14 Four Italian productions between 1920 and 1971 are reported by d'Amico (Notizia, 107-08). Firth's "Performances of Pirandello's Plays in Britain and Ireland, 1922-1999" lists seven stagings, a decidedly small number compared to the forty-two of The Man with the Flower in His Mouth (L'uomo dal fiore in bocca), Pirandello's most successful one-act play. Callan's "Ways of Staging Pirandello's Theatre" describes his experience of directing both these one-acts together in London in 1988. Hampton gives a more detailed account of some of the English performances, but finds it difficult to trace an "English line" for the play ("Pirandello in Performance," 64-67). As for the United States, a reading was organized by the Pirandello Society of America in New York with John Turturro as Cecè in 2006.

15 Pullini, "Il primo Pirandello," 41.

16 Borsellino, Ritratto e immagini di Pirandello, 131.

17 Luti, "Struttura degli atti unici di Pirandello," 152.

18 Jacobbi, "Riflessioni sugli atti unici pirandelliani," 91.

19 Callan, "Ways of Staging Pirandello's Theatre," 59.

20 Puppa, "Atti al plurale," 94.

21 Pullini, "Il primo Pirandello," 42. 
the modernist, conflictual approach with conventional logic that has become one of Pirandello's most appreciated traits. At the same time, the play's apparent superficiality leaves the door open for a series of critical angles not necessarily tied to direct authorial influence. The assumption here is clearly not that Pirandello wrote a postmodernist play; rather, that a postmodernist reading of a realist and modern play may "encourage [...] formal differences that become apparent in texts when the demand for unified interpretation is lifted." 22

Of course, even though deconstructionist theory would defer closure indefinitely, in practice a real theatre production has certain limits in time and space. It soon becomes necessary to strike a balance between multiplicity and infinity, with an eye to both quantity and quality. As for quantity, it seems that two repetitions alone, albeit an option, would risk replicating the binary oppositions so targeted by deconstructors. Therefore, there should probably be three iterations as a minimum; after the third, the rules of the game become evident and the audience expects that a new supplement might follow. The maximum number depends on at least two factors: the time available for the performance in relation to the play's length and the quality of the interpretations.

Gerald Rabkin underscores that "[d]econstruction does not assert that anything goes, that all interpretation is equal. [.. .] a strong misreading must be rigorous, tied to a theoretical framework meticulously expressed." 23 In turn, Umberto Eco links the openness of "unlimited semiosis" to a strong relationship with the material under scrutiny: "The limits of interpretation coincide with the rights of the text (which does not mean with the rights of its author)." 24 Instead of simply projecting one's drives onto the text, there should remain "a dialectical link between intentio operis and intentio lectoris." 25 Therefore, despite considerable freedom from authorial intentions, the aim here is not simply to use the text and generate a stylistic exercise, but rather to illuminate the material itself through multiple interpretations.

Elinor Fuchs suggested that "one of the meanings of 'postmodern' [... is] a dispersed idea of self." 26 This idea is intimately embedded in the

22 Fuchs, The Death of Character, 11.

23 Rabkin, "The Play of Misreading," 59.

24 Eco, The Limits of Interpretation, 6-7. For Eco, Peirce's "notion of unlimited semiosis does not lead to the conclusion that interpretation has no criteria. [...] To say that a text potentially has no end does not mean that every act of interpretation can have a happy ending" (The Limits of Interpretation, 6).

25 Eco, The Limits of Interpretation, 58.

26 Fuchs, The Death of Character, 9. 
play thanks to the protagonist's speech on the relativity of his own self, a germ of the novel One, No One, and One Hundred Thousand (Uno, nessuno e centomila). ${ }^{27}$ At the same time, the attitude in Cecè remains light-hearted enough to resonate fully with the playful disposition that characterizes postmodernist activities, in contrast with the modernist mourning for the loss of a unified identity. In Ihab Hassan's words, "postmodernism veers toward open, playful, optative, disjunctive, displaced, or indeterminate forms, a discourse of fragments, an ideology of fracture, a will to unmaking, $[\ldots]$ veers toward all these and yet implies their very opposites, their antithetical realities." 28 Indeed, our very lack of knowledge about the true nature of this protean character offers a springboard to encourage different versions and create a multifaceted yet unified show that is always open to further contributing voices.

In the following virtual staging of the play-at the same time a project for an actual production — the postmodernist aesthetics resides in the overall frame within which the playtext is repeatedly reinterpreted. Since the point is to show the contextual coexistence of markedly different voices, the perspectives are deliberately limited by downplaying their reciprocal connections and magnifying the bias of each stance. For the director, this means choosing potential interpretations based on maximum opposition among the "signs" that synchronically appear with the others. But this is no structuralist, Saussurean system, since the signifier remains, more or less, the same (Cecè), while the signified is always different (the director's interpretation). 29

As a starting point, let's say-in Jakobsonian semiotic terms-that each version will privilege one of the three main components of communication at the theatre: the original sender (the author), the message (the script itself), and the receiver (the audience), thereby mirroring the subsequent developments of critical theory from positions more attached to the author's words to a heightened emphasis on the other components of the communicative circuit. ${ }^{30}$

27 d'Amico, Notizia, 106.

28 Hassan, "The Question of Postmodernism," 125.

29 In a deconstructive context, "[s]ignifiers and signifieds [. . .] only approach each other by interpretive approximation" (Costantinidis, Theatre Under Deconstruction?, 108).

30 Naturally, given the amount of studies on each theory and theatrical technique mentioned, the following can only be a simplified exploration and citations have purposely been kept to a minimum. 


\section{Cecè One: The Author between Psychoanalysis and Intertextuality}

While writing Cecè in July 1913, Pirandello was living in his Sicilian villa named "Chaos." 31 In a letter of 24 April 1890 from Bonn, he had expressed his ideal of solitary creation in these terms: "I wish I could withdraw and live completely alone in that villa of birth, so as to dedicate myself entirely to the work I was born to do." 32 Roberto Alonge stresses the meaning of the villa in psychoanalytic terms as a "return to the state of fusion with the mother, in the solitude of 'Chaos,' filled with artistic sublimation. Art is set against every other interpersonal tie and, in the first place, against the weight and necessity of marriage." 33 If the letter had been penned at the time of the broken engagement with his cousin Lina, now Pirandello had to share the villa with his wife Antonietta, married in 1894, and their three adolescent children. We can assume that such a crowded situation was not exactly conducive to serene artistic creation, especially since Pirandello's wife had long started showing signs of the nervous weakness that would lead her to insanity. ${ }^{34}$

Since the author's vision is to be privileged, one could as well put him on the stage: our first version sees Pirandello alone, in the act of composing the one-act play. Because the villa in general cannot function as the secluded womb for his artistic daydreaming, Pirandello the character has taken refuge in his studio. ${ }^{35}$ The stage is enshrouded in partially transparent gauze, a nice way theatre offers to create a palpable fourth wall that lets the audience see the action, while excluding it from the character's and actor's circle of attention. ${ }^{36}$ Thus, the spectators have something in common with the playwright's family: both are distracting elements kept at a distance beyond the limits of the conscious. In terms of acting technique, the situation corresponds to Konstantin Stanislavsky's concept of "public

31 d'Amico, Notizia, 105.

32 Providenti, Lettere da Bonn, 1889-1891, 113.

33 Alonge, Luigi Pirandello, 6.

34 Giudice, Luigi Pirandello, 252.

35 Freud equates night dreams with fantasies manifested during the day as a way for the artist to "throw off the too heavy burden imposed on him by life" ("Creative Writers and Day-Dreaming,"145).

36 Stanislavsky's system as set forth in An Actor's Work "trains concentration through circles of attention that can be small, medium, or large. He calls points of focus on stage (whether animate or inanimate, visible or imagined) objects of attention. Actors learn to limit their focus to only those objects within defined circles" (Carnicke, "Stanislavsky’s System," 10). 
solitude," a psychophysical state in which "actors tune out anything external to the world of the play. They behave in public as if in private." 37

One of the classic methods of Freudian psychoanalysis is to analyze the author by reading his work as sublimation of repressed elements and otherwise unattainable desires. ${ }^{38}$ More specifically, applying Erik Erikson's notion of "identity element" to playwriting, Margaret Brenman-Gibson argued that "in any body of work subconfigurations of the playwright's identity structure [. . .] appear as the various casts of characters. They are the playwright's distribution of himself." 39 As a consequence, "their conflicts and resolutions [reflect] the playwright's effort via Form to bring these dualities into harmony, restoring wholeness where there was conflict." 40

Following this line of thought, the character of Cecè can be viewed as a portrayal of the relatively rich young Pirandello during his studies in Germany. There, sponsored by his father, he could afford to rent two luxurious rooms $s^{41}$ that match Cecè's "combination sitting room and study in a first-class hotel, furnished in the latest style." $42 \mathrm{Nada}$, in turn, resembles the sexually unprejudiced Jenny Lander met by Pirandello at a masked ball. On that occasion, she was wearing an enormous straw hat ${ }^{43}$ and a fascination with hats has transferred directly to the play's character. ${ }^{44}$ In a way, the dyad Cecè/Nada represents the Freudian pleasure principle: a past in which Pirandello had youth, money, and sexual fulfillment, far away from repressive Sicilian morality.

37 Carnicke, "Stanislavsky's System," 9. Although the Russian pedagogue’s system included more physical ways of accessing creativity, "[i]n the United States, Stanislavsky's work with emotion answered the American fascination with Freudian psychology" ("Stanislavsky's System," 8). The concept was later developed by Lee Strasberg as the "private moment." With his Method, Strasberg wanted to train a type of actor who "can create out of himself" by appealing "to the unconscious and the subconscious" (Strasberg, Strasberg at the Actors Studio, 81-82).

38 Giudice's biography of Pirandello, for instance, explicitly tries to draw Pirandello's psychological portrait by digging into the strong autobiographical component that permeates his oeuvre (Luigi Pirandello, 180-81).

39 Brenman-Gibson, "The Creation of Plays," 191.

40 Brenman-Gibson, "The Creation of Plays," 202.

41 See Giudice, Luigi Pirandello, 115.

42 Murray, Chee-Chee, 141.

43 Giudice, Luigi Pirandello, 123.

44 Freud saw the hat as a relatively straightforward, but also ambiguous sexual symbol: "a woman's hat can very often be interpreted with certainty as a genital organ, and, moreover, as a man's" (The Interpretation of Dreams, 5: 354-55). 
By contrast, with its obvious Oedipal connotations, Squatriglia's walled-up eye lost in a mine explosion feels like "a displaced castration symbol" 45 that materializes Pirandello's sense of a halved life. His sexuality needs to be restrained, given the difficult rapport with his jealous, but also intellectually and emotionally distant wife. ${ }^{46}$ In addition, when Squatriglia is asked to pretend that Cecè's family is ruined, this is the playful resurfacing of real, traumatic events. In 1903, the flooding of the sulfur mine, on which Pirandello's father had invested his entire capital including Antonietta's dowry, had marked the beginning of serious economic hardships and of Antonietta's mental problems. ${ }^{47}$ In a sense, Squatriglia embodies the frustrations of the reality principle and the author's present self who has directly suffered from the consequences of his reversal of fortune. ${ }^{48}$

With this in mind, Pirandello's fantasy in writing Cecè may be described as an attempt to exorcize his present self and regain the sense of power, luxury, and unattached freedom of his past self. At first, Cecè does not even remember the commendatore exactly, has literally repressed the details, and can only confuse him with someone who is just another symbol of castration, Squatriglia's brother who lost a hand. Then, Squatriglia is "squeezed" emotionally and financially as much as possible and finally thrown out of the picture. Cecè, instead, not only obtains Nada and her favors at no cost for himself, he also receives more money through her from Squatriglia. In other words, the play shows a victory of the id and its immediate, boundless wants over the ego and super-ego with their limitations and expectations. In this way, the creation of the play no longer seems to stem from nowhere, but operates as a wish fulfillment. Version number one thus becomes an inquiry into the author's psyche by connecting his known biography with creative effort, which suggests the liberating realms of daydream, fantasy, and eros.

On the stage, these insights can take different forms. In line with a strongly realistic style, the author can be surrounded by photographs and

45 Callan, "Ways of Staging Pirandello's Theatre," 55.

46 Giudice, Luigi Pirandello, 250.

47 Giudice, Luigi Pirandello, 175-76.

48 Squatriglia could also act as an image of Pirandello's father, here deprived of an eye as punishment. With him Luigi had an ambivalent relationship, since he accepted his money, but detested his person and exploitative practices in the sulfur mines that supported his family. Despite all these possibilities for analysis, one of the most lucid psychoanalytic studies of Pirandello's oeuvre, Gardair's Pirandello, fantasmes and logique du double, still dispatches Cecè in half a page as "something less than a vaudeville, a 'trickery" (85). 
objects from his student years in Germany, items from the sulfur mine, and every detail that could trigger emotional memories. Then, Pirandello's use of a real or imagined mirror to rehearse potential creative outcomes can generate a series of Lacanian mirror-stage moments in which the three characters recognize their newborn identities at the moment of their creation. In fact, this is a one-man show, where playing all the characters is a perfect way for Pirandello to reconcile his ardent desire for the theatre with his blame for the performers' lack of ideal perfection. ${ }^{49}$ Since the play lives in a purely narcissistic universe, the ending in which Nada kisses Cecè verges on autoeroticism.

This phase of the play's history is particularly significant since the script is still in flux and there are no limits to how and in what direction the text might develop. In post-structuralist terms, the psyche itself is just another intertextual plane intersecting all others. Real-life events, other works, or music from the outside, practically every aspect of the playwright's experience can be integrated to compose the final output. Puppa highlights the borrowings from the language of melodramatic libretti50 and an opera in the background seems very appropriate. But let us see a few other examples.

The shrewd Cecè and one-eyed Squatriglia form an odd couple whose origin can be traced in the episode of the Odyssey in which Ulysses, the trickster par excellence, introduces himself as "No one" and manages to escape the Cyclops's fury. Pirandello could start the show reading Homer's episode aloud, or even the satyr play by Euripides he previously translated into the Sicilian dialect. Another source of written influence could be a newspaper with an article about Pepè Malato, former mayor of Agrigento and well-known viveur at the time. 51

As for aural inspirations, the protagonist's name, a posteriori a shortening of Cesare, could arise on the spot from a phonic association of the type described by Roman Jakobson in "Linguistics and Poetics." 52 As such it would be a language-dependent choice. In Italian it could originate from the writer involuntarily overhearing a dialogue between his family members, whose last lines are "C’è! C’è!" ("there it is!") or from the insisted offer

49 Expressed, out of utter frustration with the theatrical system, as early as 1908 in the essay "Illustrators, Actors, and Translators" ("Illustratori, attori e traduttori"). Here, Pirandello is solipsistically translating himself, creating the characters from his own body and biographical material.

50 Puppa, "Atti al plurale," 94.

51 d'Amico, Notizia, 106.

52 Jakobson, "Linguistics and poetics," 357. 
of a soup of ceci (garbanzo beans) by Pirandello's wife in one of her moments of insanity; in English, Chee-Chee, as the name has regularly been translated, could derive from the author himself trying to calm his wife: "Chill! Chill!"

Furthermore, at the very moment of its creation, the play does not conform to the perfection demanded by its authorial super-ego. Therefore, all textual variants are available and this is a unique opportunity for the actor to pronounce pieces of a play that have been expunged for good, for example the few included in the Mondadori edition. Moreover, instead of playing the script in its finished form, the scenes can appear in any sequence as intentionally chaotic fragments of a performance in Dada style. Finally, diction can afford moments of lack of clarity or even murmuring, obviously with several cuts. In this way, this first version offers the "negative" of the definitive play, its free-roaming, usually hidden unconscious.

In regard to the dialogues, only some chosen moments are actually performed, with the actor moving to the different positions taken by each character, changing his attitude, voice, physical type, or trying out text and diction, at times even sounding a little strange and off-key. What counts here is the creative flow that, however hampered by the difficulties imposed by form and language, attempts to produce the artistic object at all costs. Since the atmosphere is dreamlike, the author can impersonate not only the characters, but their archetypes such as the giant Polyphemus. He does not need to act well, but has the task to offer possible versions, and not necessarily those that will be realized in the subsequent parts.

Brenman-Gibson observed that "a play always deals at some level with the playwright's view, conscious and unconscious, of the nature of the creative process itself." 53 If a lead character can be assigned to each version, this one belongs to Squatriglia, who represents the special state between conscious and unconscious (one eye open, the other closed) in which artistic vision is manifested.

\section{Cecè Two: The Script between Structuralism and Marxism}

If we foreground the script itself, independently from its author or his psyche, we can view the play as an autonomous entity. In this second version, abstraction prevails and conflicts become oppositions within a closed system. In the structural semantics of Algirdas-Julien Greimas, "the semantic microuniverse can be defined as [...] a signifying whole only to the extent that it can surge up at any moment before us as a simple drama, as an

53 Brenman-Gibson, “The Creation of Plays,” 202. 
actantial structure."54 For Cecè, using the categories of Subject/Object, Sender/Receiver, and Helper/Opponent of the Actantial Mythical Model, 55 and keeping in mind that a single actor (= character) can encompass multiple actants, ${ }^{56}$ there can be at least two configurations depending on the object of desire: in the past it was Nada, in the present it is the IOUs. The two overlap in the action of the play:

Past: $\quad$ friends' bet (sender) $\rightarrow$ Nada (object) $\rightarrow$ Cecè (receiver) IOUs (helper) $\rightarrow$ Cecè (subject) $\leftarrow$ Nada’s beauty (opponent)

Present: Cecè (sender) $\rightarrow$ IOUs (object) $\rightarrow$ Cecè (receiver) Squatriglia (helper) $\rightarrow$ Cecè (subject) $\leftarrow$ Nada’s greed (opponent)

From this example, it is clear that Cecè is truly the protagonist because the actants he clusters (i.e., his identities) are more varied and powerful, especially concerning the subject position. By contrast, Nada is either an object or an opponent, but never a subject. We will return to this point from a feminist perspective in version three.

In this context, stage props are necessary only as their functions: when Squatriglia is announced and Cecè answers, what matters for the function of a "telephone" is not so much the physical object, but a sequence of audible rings. At the performance level, the signified is essential, but the specific signifier does not matter as much. The actors can mime the phone receiver with their hands, or, even less realistically, emit the rings as if they were far from each other, with no gesture at all.

An application of the same principle to the characters' appearance could explain Cecè's difficulties in identifying the commendatore. Squatriglia, like his brother, is missing something, but they are very different body parts. If the problem of the missing eye were solved, rather than through elaborate make-up, by the performer using a hand to cover it, this would be an original interpretation of the stage direction ("has had the wound closed by a skin graft [taken from another part of the body?"), 57 and could also offer a justification of Cecè's confusion. ${ }^{58}$ By using his hand to cover one of the eyes, Squatriglia somehow misses both and, therefore, makes the mistake "credible" in its absurdity.

54 Greimas, Structural Semantics, 199.

55 Greimas, Structural Semantics, 207.

56 Greimas, Structural Semantics, 203.

57 Murray, Chee-Chee, 142.

58 "CECÈ. You see, I remember. Yes. Filippo. He has only one eye and you - that is, he has only one hand and you have only one eye, yes, that's it!" (Murray, CheeChee, 145). 
Evidently, non-realistic theatrical practices would serve this version much better. Here, a director can differentiate the two levels of characters and performers by applying a combination of techniques inspired by two crucial theatre theorists who rejected illusionistic theatre, Vsevolod Emilevich Meyerhold and Bertolt Brecht.

In contrast with Naturalism's more individualistic vision, Meyerhold's Biomechanics training for the actor is "orientated towards collective, integrated, and nonindividualistic stage action." 59 Through an emphasis on physical control, rhythmic awareness, and readiness to react to external stimuli,60 Meyerhold's formalist approach can help to foreground the abstraction of Cecès structure. In his style, the set depends strictly on its functions for meaning, so that a simple platform can easily become the room's door, a table, or a bed as needed.61 Also, whiteface make-up may enhance the sense of the social masks used by each character as the action progresses. 62

In turn, using Brechtian epic techniques, the three dialogues can be performed not as a continuous story but as episodes, separated by very definite pauses in which the actors change their costumes or interject small talk about their personal lives. While stage directions can be read aloud or presented on signboards, the lines serve to arrive at the Gestus, "the social heart" of each episode ${ }^{63}$ and "an absolutely transparent physical elucidation of the fable." 64 For instance, from a Marxist perspective, the economic base

59 Worrall, "Meyerhold's Production of The Magnificent Cuckold," 16.

60 Leach, "Meyerhold and Biomechanics," 32.

61 Honzl recalls that in Meyerhold's stagings "we frequently see a system of suspended planes, staircases and props whose meaning as a sign is completely indeterminate. [...] His stage sets had very concrete tasks and functions. Indeterminate in shape and colour, they became signs only when used for the actor's actions" ("Dynamics of the Sign in the Theatre," 272). For the polyvalence of the theatrical sign, see Kowzan, Sémiologie du théâtre, 101-11.

62 Pitches clarifies that "[w] hen Meyerhold talks of the mask he does not necessarily mean the kind which is made of paper, leather or wood and worn over the face by an actor. [...] Masks can be created by make-up, by hairstyle, by facial expressions, or by any technique which defines a character in terms of its external characteristics" (Vsevolod Meyerhold, 58). In addition, masks are not necessarily fixed all the time: "[a]t any given moment, Meyerhold's actors were asked to present a theatricalised 'mask' to the audience. But as the plot (or intrigue) developed, the character required a new mask" (Leach, "Meyerhold and Biomechanics," 30).

63 Thomson, "Brecht and Actor Training," 123.

64 Rouse, "Brecht and the Contradictory Actor," 299. 
becomes central: in Cecè, the IOUs or the cash given to Nada by Squatriglia, together with the theme of money, lost or exchanged for sex, can all be stressed by pauses, lighting solutions, or a concluding tableau for each dialogue.

Specifically, what can gain in clarity is the theatricality of the middle scene, "a minuscule seed" of Pirandello's recurring interest for a metatheatrical situation. ${ }^{65}$ In fact, the moment when Squatriglia plays the part imposed by Cecè is a micro play within the one-act in which both interlocutors are pretending, since the bill that Nada claims still unsettled has already been paid by Cecè. And, once this process of mise en abyme is acknowledged, the perspective can even expand in the opposite direction.

The show thus starts with two nested outer frames wrapped around the playtext: the preparation of the stage by the performers, followed by a synthetic but textless rendering of the sole physical blocking in rapid sequence as if during a rehearsal. If, at the conclusion of the latter, the phone rings again because the whole play starts over, the spectators perceive a circular text, in which Cecè is undressed at the beginning because he has just seen Nada in the previous iteration and is preparing to see her once more. Since certain facts are explained in a purely mechanical way, logic loses its grip and realism is further destabilized.

In theory, the show could continue without end, gradually increasing its speed until the performers physically collapse. In Marxist terms, this mechanism enhances the sense of oppression for both characters and performers involved in such a theatrical assembly line. At both levels, they are forced to repeat themselves: the characters without realizing it, the performers in full conscience. This double awareness can be made apparent by alienating effects, such as sudden shifts between the official, textual, and masked version of Cecè and flashes in which the performers surface as human beings and demonstrate their discontent and exhaustion, possibly against a stage-manager who insists on more and more rehearsals. In this way, show business becomes an Althusserian apparatus whose ideology proclaims that the show must go on at all costs and whose subjects end up "work[ing] all by themselves." 66

In a sense, the split between the comic playtext and the difficulties of performing it as a chore becomes an embodiment of Pirandellian humor as "feeling of the opposite." Should we choose the lead character for this version, it would undoubtedly be Cecè himself, at the same time perfect executor of the mechanism and, with his scattered self, victim of its repetitions.

65 Pullini, "Il primo Pirandello," 43.

66 Althusser, "Ideology and Ideological State Apparatuses," 182. 


\section{Cecè Three: The Audience between Phenomenology and Feminism}

The two previous versions privilege the auto-reflexive component: in the first, an actor interprets the author who performs a show for himself alone; in the second, the performers demonstrate the abstractions of structure while experiencing their condition as cogs of a mechanism, but once again excluding the audience. The time has come to shred the cocoon and actively involve the spectators. By adopting a feminist stance, Nada finally has an opportunity to become the main reference character.

In her study of Pirandello through the lens of gender, Maggie Günsberg observes that while the writer's "alignment with the mainstream cultural encoding [...] is not surprising, given his position as a middle-class male born into the archetypally traditional society and culture of Sicily in the 1860s," it is interesting to notice how his works "reproduce and reinforce the status quo of gender relations." 67 Specifically, Cecè is a typical example of female objectification:

In the male-dominated context of the original bet [. . . the female character is excluded from the discourse which articulates her function as object of exchange, and which names her price. [. . .] It is then Cecè who, having succeeded in his quest, decides what she is worth. The entire plot revolves around his decision to reduce this price, and the collusion of a male friend who helps him to outwit Nada into accepting the reduced rate. 68

Pirandello frequently portrays women as antagonists, ${ }^{69}$ rather than protagonists, and this is reflected here in the very limited amount of lines of monologue assigned to Nada. ${ }^{70}$

Several of the theories suggested for our first Cecè-from the prominence of authorship to psychoanalysis, from realism to Stanislavskian and Method acting - have been criticized by feminist scholars for subscribing to the patriarchal order and for producing a theatre dedicated solely to the fulfillment of male desire, where women are objectified through the pervasive, but limited perspective of the male gaze. In Feminism and Theatre, Sue-Ellen Case advocates a "new poetics" that "would deconstruct the traditional systems of representation and perception of women and posit women in the position of the subject." To this purpose, she suggests that

\footnotetext{
67 Günsberg, Patriarchal Representations, xi.

68 Günsberg, Patriarchal Representations, 60-69.

69 Günsberg, Patriarchal Representations, xiii.

70 Günsberg, Patriarchal Representations, 60.
} 
"an effective starting-point for the intersection of new theory with performance and feminist poetics may be found in the field of semiotics." 71

This is especially true for the reception-oriented semiotics that was born out of a shift-mediated by Eco's The Role of the Reader-from Saussure's signifier-signified dyad to Charles Peirce's system, based on triads. One of the most important of these triads is sign-object-interpretant, which connects the theatre with its surroundings, from its immediate audience to the entire culture. ${ }^{72}$ It is at this intersection that semiotics can also be integrated with its complementary "phenomenological attitude." Bert States clarifies that the audience constantly receives a double message during a performance, both the semiotic meaning and, at the same time, the direct perception of the real objects and bodies of the performers. If "phenomenology is an effort to recover what in our experience has been 'annihilated ... by reiteration," "73 it can also serve here as a counterpart to our hyper-mechanized version two.

Equipped with this awareness, a feminist approach may want to reevaluate the usually demeaned "inferior discourse of the body" 74 and, through dialogue with the audience, attempt to steer the playtext in a different direction. Thus, the third version begins as the performers mingle with the spectators and group them in three distinct parts, one of which might include women alone. The intent is to focus on specific episodes and tap into their sensory and sensuous aspects. Cecè imagines himself in his friends' company before accepting the bet and offers fresh aromatic coffee to the spectators; simultaneously, Nada asks a woman in the audience to help her dress up, while showing off her new clothes and inviting her or others to touch and feel their fine fabric; Squatriglia, in turn, recounts his favorite story, the atrocious details of the bomb explosion and his eye surgery.

71 Case, Feminism and Theatre, 115.

72 Carlson, "Semiotics and Its Heritage," 19. For a summary of positions concerning theatrical reception, see the chapter "The Spectator's Task" in De Marinis, The Semiotics of Performance, 158-88. In a more recent study, Lotman draws a distinction between early formalism and contemporary structural analysis: in contrast to the former's emphasis on the isolation of the object, the latter views the text "as a functional rather than a stable object with constant properties," which implies the potential for its expansion within the semiosphere (Culture and Explosion, 114-15).

73 States, "The Phenomenological Attitude," 31. States is quoting Shelley's $A$ Defence of Poetry.

74 Günsberg, Patriarchal Representations, 52. 
Once the threshold of the Pirandellian text approaches, each character tries to consolidate the intimacy with one of the three groups by promising a present at the end, if they will actively support him or her during the show. Hence, the circuit of favors that prompted Squatriglia's visit now extends beyond the fourth wall. At this point, the basic events of the play have been learned and there is no need to perform them in full. As in some recent video commercials, the action can undergo sudden accelerations in the most "arid" parts of pure action, or can instead slow down when it becomes possible to secure better support from the audience against the other two groups. Every opportunity can be seized for improvisations outside the Pirandellian script: Cecè asks the group he is trying to charm if they like the scent of his shaving foam; Squatriglia complains for the chore assigned to him and entreats someone for some money as soon as Nada becomes greedy, even greedier in this version.

Albeit in this atmosphere of enhanced freedom from the script, some specific lines are very present. Essential remains Cecè's statement about his distracted approach to his connections:

People who know you and whom you don't know? Who know everything about you and whose names you can't even remember? Whom you have to smile at, slap on the back, and say "dear" or "darling" to, and all the time you're up in the air, trying to pretend you aren't, while you do your best to remember, to be interested? And meanwhile you're asking yourself, "And who's he? Where does he know me from? Who am I to him?"75

At these words, uttered with a certain contempt, the spectators-even the group initially fascinated by the man's charisma-would probably rebel within, as they perceive the falsity of the previously established relationship. Later on, in the dialogue with the commendatore, Cecè can underscore his pronounced male chauvinism by contrasting his physical appraisal of Nada ("the original Eve!"76) with the little value he attributes to her ("four hundred, five hundred lire. Not more, understand? It wouldn't be worth it!"77). Even her name means "nothing" in Spanish and English.

Since the "silencing" of the female roles" often means that the words for resistance simply are not there, ${ }^{78}$ the feminist performer may need to step outside the play in order to obtain a position as subject. In fact, one

75 Murray, Chee-Chee, 144.

76 Murray, Chee-Chee, 150.

77 Murray, Chee-Chee, 151.

78 Aston, Feminist Theatre Practice, 95. 
of the directions pursued by feminist theatre practice has been to deconstruct canonical "master" texts by "tak[ing] on the role of resisting agent or performer who functions as an ideological, cultural and theatrical demonstrator-empowered as the feminist critic (rather than female victim)." 79

Thus, once Nada wins her little game with Squatriglia, she has gained total power and can decide not to follow the script altogether, interrupt the action, and ask the audience to report what Cecè actually said about her. The ending can be open, not defined by either author or director, but left to the cooperation between actress and audience each evening. In any case, either with a sarcastic laugh or with the fury of an Agave springing at Pentheus in Euripides's Bacchae, the final result should be a highly embarrassed Cecè, in his underwear (or less...), definitively deprived of his clothes. Once they have been reduced to rags by Nada, they can be offered to the spectators as the promised gifts. In this way, during the entire evening, the audience witnesses the complete journey of the script from the author's psyche to the gift of a concrete "piece" of the play to be taken home at the end of the show.

Elaine Aston underscores that feminist practice differs from others in that it "does not follow a predetermined set of rules; it is not designed to 'fit' a 'theory' [. . . but] 'steals' or draws on whatever is necessary, from wherever it is needed, to oppose categorization." 80 Therefore, beyond the more "liberal" version suggested above, which still works to improve the existing system from within, other options could be equally viable. A radical feminist approach could cast all female performers and ask the male spectators to exit the hall. A materialist feminist interpretation could employ strategies from the "arsenal" of the Theatre of the Oppressed developed by theatre practitioner Augusto Boal, and aim at transforming the spectators, male and female, into resistant, revolutionary "spect-actors" in order to effect change in the real world. ${ }^{81}$

79 Aston, Feminist Theatre Practice, 83.

80 Aston, Feminist Theatre Practice, 18.

81 In contrast with both Aristotle and Brecht, Boal's "poetics of the oppressed focuses on the action itself: the spectator delegates no power to the character (or actor) either to act or to think in his place; on the contrary, he himself assumes the protagonic role, changes the dramatic action, tries out solutions, discusses plans for change-in short, trains himself for real action. In this case, perhaps the theatre is not revolutionary in itself, but it is surely a rehearsal for the revolution" (Theatre of the Oppressed, 98). 


\section{A Theatre of Theory}

In the three examples above we have seen some of the ways in which critical theory can consciously cooperate with theatrical practice and engender a "theatre of theory." 82 Clearly, the points of access to a specific play are as many as the text will allow, but each door implies a series of consequences on acting style, set design, and audience participation. At the same time, no matter how fiercely despotic each perspective may be, ${ }^{83}$ the brevity of the one-act play places them all within the same immediate context. With a full-length play, the audience would normally go home with a monologic experience, a psychoanalytic, or a materialist, or a feminist reading, for instance. With a short play, the conjunction is and: from the first to the last, all interpretive keys can be explored and can co-exist in dialogue with each other.

The advantage of a virtual staging like this is that it can approach the playtext more boldly, without immediately taking into account copyright restrictions. The method of engaging multiple perspectives can serve as creative gymnastics for directors, at the same time a technique of inner questioning in preparation for actual productions (of this or other plays) and an encouragement to direct in team with others. However, the approach can certainly function in practice: more minimalist versions based on an identical text are always possible, and younger generations of playwrights seem more open than ever to experiments. What is more, thanks to the short play's innate dialogism, the postmodernist angle can thrive without the need of a theory-intensive environment or even professional directors.

In actual fact, I used the play extensively during an undergraduate course dedicated to the Italian theatre between 1880 and 1950. Critical theory could only be mentioned in passing, but freedom from authorial control was guaranteed by the class/workshop setting. During the first part of the semester, the students compiled a list of the play's essential actions, so that it could easily be improvised or resized. Along the way, small groups presented a version in each style studied during the course: there was a grotesque version, a Futurist sintesi, and so on. Finally, four original ideas

\section{Schmidt, The Theater of Transformation, 22.}

83 Each monologic version does tend to appropriate the others. From the viewpoint of version number one based on psychoanalysis, the repetitions are ways of "working-through" the same situation with increasing awareness; for the "mechanized" version number two, the others are segments of an alienating assembly line; for version number three, they are necessary examples of ingrained sexist patterns and opportunities for inspired deconstructions. 
were chosen to be produced together. The full show, Chaz, contained a college version set in a dorm; an eighteenth-century darker adaptation; a meeting of the elderly Chaz and Nada at a bus stop with flashbacks into the past; and a sock puppet show, the most hilarious version and, I should say, definitive proof of the writerly qualities of the play. ${ }^{84}$ Thus, the same qualities that make Cecè so appropriate for this virtual experiment also make it a valuable teaching tool.

In our multifaceted Cecè, the diversity of points of view has been absorbed into the director's work as an encouragement to continue questioning the dramatic material. As Cecès identity is defined by the people who meet (and interpret) him, so postmodernism lives in the multiplicity of versions and the freedom to put all viewpoints in practice at the same time. In sum, within the flexible postmodernist framework afforded by the short play, all readings become enlightening supplements to a theatre of theory, not only abstract ideas, but tangible realities.

\section{GetTysburg COllege}

\section{WORKS CiTED}

Alonge, Roberto. Luigi Pirandello. Rome: Laterza, 1997.

Althusser, Louis. "Ideology and Ideological State Apparatuses (Notes Towards an Investigation)." Lenin and Philosophy and Other Essays. Trans. Ben Brewster. New York: Monthly Review Press, 1971. 127-86.

Aston, Elaine. Feminist Theatre Practice: A Handbook. London: Routledge, 1999. Auslander, Philip. "Postmodernism and Performance." The Cambridge Companion to Postmodernism. Ed. Steven Connor. Cambridge: Cambridge University Press, 2004. 97-115.

Barthes, Roland. "From Work to Text." Image, Music, Text. Comp. and trans. Stephen Heath. New York: The Noonday Press, 1977. 155-64.

—. "The Death of the Author." Image, Music, Text. Comp. and trans. Stephen Heath. New York: The Noonday Press, 1977. 142-48.

—. S/Z. Trans. Richard Miller. New York: Hill and Wang, 1974.

Bertens, Hans. The Idea of the Postmodern: A History. London: Routledge, 2002. Boal, Augusto. Theatre of the Oppressed. Trans. Charles A. and Maria-Odilia Leal McBride and Emily Fryer. London: Pluto Press, 2008.

Borsellino, Nino. Ritratto e immagini di Pirandello. Rome: Laterza, 1991.

84 The name of the show, Chaz, derives from Charles as Cecè is a shortening of Cesare. The usual Chee-Chee sounded demeaning for the character and the students fully adapted the process, rather than the sound (as previous translators have done). 
Boselli, Stefano. "The Intertextual Short Play: An Example Using Verga's Cavalleria rusticana and Capuana's Il piccolo archivio." MLN 126.1 (2011): 47-72.

Brenman-Gibson, Margaret. "The Creation of Plays: With a Specimen Analysis."

Psychoanalysis, Creativity, and Literature: A French-American Inquiry. Ed. Alan Roland. New York: Columbia University Press, 1978. 178-230.

Buse, Peter. Drama + Theory: Critical Approaches to Modern British Drama. Manchester: Manchester University Press, 2001.

Callan, Guy. "Ways of Staging Pirandello's Theatre; And, Cecè: Notes of An ActorDirector.” Pirandello Studies 20 (2000): 48-61.

Carlson, Marvin. "Semiotics and Its Heritage." Reinelt and Roach 13-25.

Carnicke, Sharon Marie. "Stanislavsky's System: Pathways for the Actor." Hodge $1-25$.

Case, Sue-Ellen. Feminism and Theatre. New York: Methuen, 1988.

Constantinidis, Stratos. Theatre Under Deconstruction? A Question of Approach. New York: Garland Publishing, 1993.

d'Amico, Alessandro. Notizia. Cecè. Maschere nude. By Luigi Pirandello. Ed. d'Amico. Vol. 1. Milan: Arnoldo Mondadori Editore, 1986. 105-08.

Deleuze, Gilles. Difference and Repetition. Trans. Paul Patton. New York: Columbia University Press, 1994.

De Marinis, Marco. The Semiotics of Performance. Trans. Áine O'Healy. Bloomington: Indiana University Press, 1993.

Derrida, Jacques. Writing and Difference. Trans. Alan Bass. London: Routledge, 1993.

Eco, Umberto. "Innovation and Repetition: Between Modern and Post-Modern Aesthetics." Reading Eco: An Anthology. Ed. Rocco Capozzi. Bloomington: Indiana University Press, 1997. 14-33.

—. The Limits of Interpretation. Bloomington: Indiana University Press, 1990. The Role of the Reader. Bloomington: Indiana University Press, 1984.

Firth, Felicity. "Performances of Pirandello's Plays in Britain and Ireland, 1922-1999." Pirandello Studies 20 (2000): 75-100.

Fortier, Mark. Theory/Theatre: An Introduction. $2^{\text {nd }}$ ed. London: Routledge, 2002. Freud, Sigmund. The Standard Edition of the Complete Psychological Works of Sigmund Freud. Ed. and Trans. James Strachey. London: Hogarth Press, 1953-74. . "Creative Writers and Day-Dreaming." Standard Edition Vol. 9. 141-53. The Interpretation of Dreams. Standard Edition Vols. 4-5.

Fuchs, Elinor. The Death of Character: Perspectives on Theater after Modernism. Bloomington: Indiana University Press, 1996.

Gardair, Jean-Michel. Pirandello, fantasmes et logique du double. Paris: Librairie Larousse, 1972.

Giudice, Gaspare. Luigi Pirandello. Turin: UTET, 1963.

Greimas, Algirdas-Julien. Structural Semantics: An Attempt at a Method. Trans. Daniele McDowell, Ronald Schleifer, and Alan Velie. Lincoln: University of Nebraska Press, 1983.

Günsberg, Maggie. Patriarchal Representations. Oxford: Berg, 1994. 
Hampton, Simon. "Pirandello in Performance: An English Line." Pirandello Studies 20 (2000): 62-74.

Hassan, Ihab. "The Question of Postmodernism.” Bucknell Review 25.2 (1980): $117-26$.

Hodge, Alison, ed. Actor Training. $2^{\text {nd }}$ ed. London: Routledge, 2010.

Honzl, Jindrich. "Dynamics of the Sign in the Theatre." Modern Theories of Drama. Ed. George Brandt. Oxford: Clarendon Press, 1998. 269-78.

Jacobbi, Ruggero. "Riflessioni sugli atti unici pirandelliani." Milioto 89-97. Jakobson, Roman. "Linguistics and poetics." Style in Language. Ed. Thomas Sebeok. Cambridge, MA: Technology Press of Massachusetts Institute of Technology, 1960. 350-77.

Kowzan, Tadeusz. Sémiologie du théâtre. n.p.: Éditions Nathan, 1992.

Lacan, Jacques. "The Mirror Stage as Formative of the I Function." Revue Française de Psychoanlyse 4 (1949): 449-55.

Leach, Robert. "Meyerhold and Biomechanics." Hodge 26-42.

Lotman, Juri. Culture and Explosion. Ed. Marina Grishakova. Trans. Wilma Clark. Berlin: Mouton de Gruyter, 2009.

Luti, Giorgio. "Struttura degli atti unici di Pirandello." Milioto 143-61.

Lyotard, Jean-François. The Postmodern Condition: A Report on Knowledge. Trans.

Geoff Bennington and Brian Massumi. Manchester: Manchester University Press, 1984.

Milioto, Stefano, ed. Gli atti unici di Pirandello. Agrigento: Centro nazionale di studi pirandelliani, 1978.

Murray, William, trans. Chee-Chee. Pirandello's One-Act Plays. By Luigi Pirandello.

New York: Funk \& Wagnalls, 1970. 139-73.

Pirandello, Luigi. Cecè. Maschere nude. Ed. Alessandro d'Amico. Vol. 1. Milan: Arnoldo Mondadori Editore, 1986. 109-35.

"Illustratori, attori e traduttori." Saggi e interventi. Ed. Ferdinando Taviani.

Milan: Arnoldo Mondadori Editore, 2006. 635-58.

. Uno, nessuno e centomila. Tutti i romanzi. Vol. 2. Milan: Arnoldo Mondadori Editore, 1986. 737-902.

Pirandello Society of America. "John Turturro in Cecè by Luigi Pirandello." Pirandellosociety.org. 1 Aug. 2011.

Pitches, Jonathan. Vsevolod Meyerhold. London: Routledge, 2003.

Providenti, Elio, ed. Lettere da Bonn, 1889-1891. By Luigi Pirandello. Rome:

Bulzoni Editore, 1984.

Pullini, Giorgio. "Il primo Pirandello." Milioto 21-48.

Puppa, Paolo. "Atti al plurale." Parola di scena. Teatro Italiano tra '800 e '900. Rome: Bulzoni Editore, 1999. 65-97.

Rabkin, Gerald. "The Play of Misreading: Text/Theatre/Deconstruction." Performing Arts Journal 7.1 (1983): 44-60.

Reinelt, Janelle and Joseph Roach, eds. Critical Theory and Performance. $2^{\text {nd }}$ ed. Ann Arbor: Michigan University Press, 2007.

Rouse, John. "Brecht and the Contradictory Actor." Reinelt and Roach 295-310. 
Schmidt, Kerstin. The Theater of Transformation: Postmodernism in American Drama. Amsterdam: Rodopi, 2005.

Silverman, Hugh. "Jacques Derrida." Postmodernism: The Key Figures. Ed. Hans Bertens and Joseph Natoli. Oxford: Blackwell Publishers, 2002. 110-18.

Stanislavski, Konstantin. An Actor's Work. Trans. and ed. Jean Benedetti. London: Routledge, 2008.

States, Bert. "The Phenomenological Attitude." Reinelt 26-36.

Strasberg, Lee. Strasberg at the Actors Studio: Tape-Recorded Sessions. Ed. Robert Hethmon. New York: Theatre Communications Group, 1965.

Thomson, Peter. "Brecht and Actor Training: On Whose Behalf Do We Act?" Hodge 117-29.

Worrall, Nicholas. "Meyerhold's Production of The Magnificent Cuckold." The Drama Review 17.1 (1973): 14-34. 